\title{
The European Union as a Cosmopolitan Civic Space: Conceptual Backgrounds and Contemporary Challenges ${ }^{1}$
}

\section{La Unión Europea como un espacio cívico cosmopolita: orígenes conceptuales y retos contemporáneos}

\author{
MARTA POSTIGO \\ Department of Philosophy, University of Málaga, Spain
}

\begin{abstract}
At the beginning of the 21 st century, the independence and absolute sovereignty of states has become a pressing issue. The emergence of supranational organizations such as the United Nations and the European Union after World War II brings new challenges to the political hegemony and sovereignty of states. Indeed, the European integration process is forcing us to rethink the basic concepts and procedures of representative democracy and citizenship beyond the traditional state framework. This article focuses on the civic dimension of the European integration process and highlights several achievements and shortcomings of the European Union with regard to the free movement of citizens and the enhancement of European citizenship.

KEYWORDS

COSMOPOLITANISM, EUROPEAN CITIZENSHIP, EUROPEAN UNION, FEDERALISM, FREE MOVEMENT OF CITIZENS
\end{abstract}

\section{RESUMEN}

A comienzos del siglo veintiuno, la independencia y la soberanía absolutas de los estados son asuntos acuciantes. La emergencia de entidades supranacionales como las Naciones Unidas y la Unión Europea tras las Segunda Guerra Mundial plantea nuevos

1 This article is part of the academic results of The Civic Constellation Project (FFI201123388) of the Spanish National Research Plan. Herein, I take the opportunity to thank the Chair of the Project, Prof. José María Rosales, for his continuous academic stimulus and support.

(C) Contrastes. Revista Internacional de Filosofia. Suplemento 20 (2015), pp. 201-220. ISSN: 1136-9922 Departamento de Filosofía, Universiad de Málaga, Facultad de Filosofía y Letras

Campus de Teatinos, E-29071 Málaga (España) 
retos a la hegemonía política y la soberanía de los estados. De hecho, el proceso de integración europea obliga a reconsiderar conceptos y procedimientos básicos de la democracia representativa y de la ciudadanía más allá del marco del estado-nación. Este artículo se centra en la dimensión cívica del proceso de integración europea y discute los logros y debilidades de la Unión Europea con respecto a la libre circulación de ciudadanos y el desarrollo de una ciudadanía europea.

PALABRAS CLAVE

CIUDADANÍA EUROPEA, COSMOPOLITISMO, FEDERALISMO, LIBRE CIRCULACIÓN DE PERSONAS, UNIÓN EUROPEA

\section{LASTING PEACE, COSMOPOLITANISM AND FEDERALISM: MODERN PHILOSOPHICAL BACKGROUNDS AND EUROPEAN UNIFICATION}

More than two centuries ago, at the core of Prussia's Enlightenment thought, cosmopolitan ideals emerged in Europe in connection to the aim of placing states under a common civilized legal framework. Likewise, in the second half of the 20th century, after the horrors of World War I and II, international leaders laid the first cornerstones of the current United Nations system for the protection of human rights and humanitarian law, and European officials took the first steps toward Western Europe's integration in order to achieve peace and prosperity among Western democracies. Although more than a century and half divides these two events, they have significant goals and principles in common that can be seen in the federal and cosmopolitan values and principles that have been closely related in theories on international law, human rights and European integration process.

The Enlightenment's best example of an attempt to reappraise the ancient concept of cosmopolitanism in connection to the purpose of reviewing international law principles and defending lasting peace can be found in Immanuel Kant's 1795 essay, Toward Perpetual Peace. ${ }^{2}$ Therein, Kant advocated an ius cosmopoliticum (Weltbürgerrecht) or cosmopolitan law as a way of ending the «state of nature» or permanent threat of war between states and prompting the subsequent entering into a cosmopolitan legal framework (civitas gentium). According to Kant, aggression and the threat of war could best be contained and prevented through an international federation or contract (fedus) among sovereign republics that would voluntarily accept a non-aggression pact. The unwritten code of «the political right and the law of people», he wrote, could be embodied «in a public law of the humankind». Such a public law for humankind

2 Original title: Zum ewigen Frieden. Ein philosophischer Entwurf(Garrido 2005: 13). 
would prevent aggression, promote mutual solidarity and ensure lasting peace. As a result, the ius cosmopoliticum would limit the absolute sovereignty and independence of states, placing them into legal relations with one another and banning military actions. Hence, the pre-civilized international «state of nature» would be replaced by a civil contract (fedus) or cosmopolitan law (Kant 2005, 148, 155, 160; Nussbaum 1997, 25-59; Lutz-Bachmann 1997, 59).

Kant advocated a special kind of international federation, what he called a «federation of peace» (foedus pacificum), which unlike the current peace treaties (pactum pacis) would cease the state of nature and war forever, not just temporarily. In this sense, the federation of peace was intended as an alternative proposal to the current international law system. However, the foedus pacificum did not presuppose the creation of a single world-state. Unlike the idea of a single world-state (civitas maxima), Kant advocated the protection of states' sovereignty and autonomy and opposed granting constitutional prerogatives to the federation (Kant 2005, 153; Rivera 2003, 159). ${ }^{3}$

In addition to these considerations, the third article of Toward Perpetual Peace was devoted to defending the universal duty of hospitality. Although the universal right «to be permanently hosted» in a foreign country was too demanding and rather unrealistic, he argued that the temporary «right to visit» another state and be kindly treated there was a reasonable duty to be fulfilled on behalf of the law of peoples. The philosopher of Königsberg underlined two main «natural» causes of war and hostility among peoples: the plurality of languages and the diversity of religions. These uneasy divisions could nevertheless be tamed and civilized through the progressive federation of republics and a cosmopolitan law (Kant 2005, 157, 159, 167).

Although Kantian cosmopolitan commitments and ideals have been largely overshadowed by the rise of nationalism and the two world wars, the influence of his universalist approach on later generations of philosophers and jurists cannot be overlooked. As Rivera has put it, Kant's cosmopolitanism was above all federalism (Rivera 2003, 158). Likewise, cosmopolitan and federal commitments were closely connected to each other in later works by liberal and federal authors of the 19th and 20th centuries. For example, during the second half of the 19th century, Spanish krausists $^{4}$ advocated for a European federation as a crucial stage

3 In this regard, Lutz-Bachman and Jürgen Habermas have discovered some conceptual inconsistencies and contradictions that, in their view, lie in Kant's 1795 essay (Lutz-Bachman 1997, 59-79; Habermas 1997, 116-117, 127, 128).

4 As early as 1840 the philosophical ideas of the German Philosopher Karl Christian Friedrich Krause (1781-1832) were propagated in Spain by Julian Sanz del Río who also inspired Spanish liberal intellectuals and politicians known as krausists. 
in the establishment of a global alliance of humankind. In addition to Kant, they were inspired by the German jurist and philosopher Heinrich Ahrens, who had made the federalist ideal the cornerstone of his theory on public international law. It can be argued that «upon these theoretical bases Spanish krausists believed that this universal harmony could be encouraged from the municipality, through the nation, to finally embrace the progressive integration of states» (Ayzagar and Capellán de Miguel 2003, 307; see also Castaldi 2007, 1-97). ${ }^{5}$

A century and a half later, similar views reemerged in Europe after the devastations of World War I and II. In 1950s the gradual integration of Western Europe was viewed as the best solution to the excesses of nationalism and national ambitions that had in the span of a few decades triggered two world wars. The parallels between Kant's theory on perpetual peace and the ideals and goals that prompted the European integration process after World War II should not be underestimated, in spite of the disparate conceptual and historical frameworks that separate them. In the second half of the 20th century, federal and cosmopolitan concepts and goals were once again closely related to each other, and peace, along with the commitment to humanitarian principles and law, were at the core of the political ideals and moral values that inspired the creation of postwar supranational political and judicial organizations. For instance, Mario Albertini, a leading figure of the federalist movement of the interwar period, drew on Kant's cosmopolitanism in order to advocate European unification as a way of avoiding war among European states and achieving lasting peace. In general terms, in the origins of European integration, a federation was considered the only institutional formula suitable for the economic and political reconstruction of Western Europe. This view was reflected in the Ventotene Manifesto written in 1941 by two other leading figures of the European federalist movement, Altiero Spinelli and Ernesto Rossi, on behalf of European integration. Spinelli and Rossi insisted it was the twin evils of states' military escalation and fierce competition that had fuelled two world wars. In their view, the state was «no longer the guardian of civil liberty», but it had come to hold within its power «all the faculties needed to achieve the maximum warefficiency», becoming «the master of vassals bound to servitude». As a result, «children were taught how to handle weapons and hate foreigners». ${ }^{6}$ The best

5 The translation is mine.

6 The Ventotene Manifesto is considered one of the central documents of the European federal tradition. It was written in 1941 by Altiero Spinelli and Ernesto Rossi against the divisive forces of Nationalism and Fascism in Europe (Castaldi 2007, 15-31). See the Manifesto online: http://www.altierospinelli.org/manifesto/en/manifesto1944en_en.html [accessed 24 July 2014]. 
cure for such an anti-cosmopolitan atmosphere was the taming of nationalism through the progressive federation of European states (Burgess 2000, 31-32; Castaldi 2007, 15-31). ${ }^{7}$

In this regard, peace and the rescue of a cosmopolitan Europe from the grip of nationalism and totalitarianism were interconnected basic aims for European artists and intellectual elites of the interwar period. For example, one of the influential figures among European intellectual elites that opposed the rise of Nazism and Fascism was the pacifist Austro-Hungarian writer Stefan Zweig who in his writings advocated Europe's enlightened values and cosmopolitan culture. In fact, prior to the start of World War I in 1914, there were virtually no border controls or restrictions on labor mobility across the continent. After World War I, border controls were reinforced across Europe and new states were created based on ethnic backgrounds. The rise of totalitarian movements became the greatest threat to the liberal and cosmopolitan values that were once the hallmark of European culture (Zweig 1976; Arendt 1976).

In order to achieve peace as well as the economic and political recovery of Western democratic states, the so-called founding fathers of the European Union prompted Western Europe's economic and political integration. In the 1950s, market integration was viewed as a strategic tool to foster the economic and political recovery of Western European democracies. It would be hard to confirm whether the «founding fathers» of the European integration process explicitly relied on the 18th century's cosmopolitan and federal theories to create the European Coal and Steel Community (ECSC) and later the European Economic Community (EEC). More likely, Jean Monnet -one of the leading figures of the so-called functionalist approach to integration- was probably more interested in feasible achievements and pragmatic goals than in abstract ideals such as cosmopolitanism and federalism. Even so, Monnet and Robert Schuman, French Foreign Minister between 1948 and 1952, claimed that lasting peace could only be attained on the continent through the cooperation and gradual unification of European states, particularly France and Germany with regard to coal and steel production. In May 1950, Schuman declared that peace and progress could only be guaranteed through a European integration process that was viewed as a future European federation. "A united Europe was not achieved and we had war», he stated (see Monnet 1985; on European functionalism see Weiler 2012, 825-841; Schimmelfennig 2014, 1-17; Dosenrode 2010, 1-28). ${ }^{8}$

\section{Ibid.}

8 In fact, the word «federation» recurs in Robert Schuman's 1950's Declaration which gave rise to the European Coal and Steel Community (ECSC). For example, Schuman stated 
The primary goal of the ECSC, and later the EEC, was the recovery of West European states. Alan Milward's book, The European Rescue of the Nation-State has clearly illustrated this state-centered understanding of the European integration process (see Judt 2011, 121). But even if the ultimate goal of European unification was the rescue of Western democratic states from their post-war collapse, it should be noted that only through the progressive elimination of frontiers could European nations recover and aspire to a better future. Therefore, what this paradox shows is that, at least from the point of view of influential postwar intellectuals and officials, states could not recover and progress unless they cooperated with each other, opened their borders and shared part of their sovereignty. In other words, the advancement and recovery of Western Europe after the devastations of World War II depended to a great extent on states' mutual economic and political integration and cooperation (see Monnet 1985).

To summarize, in examining the roots of the European integration process one may encounter federal and cosmopolitan ideals and goals that resemble those already formulated during the Enlightenment period in connection to principles and notions of international peace and law. ${ }^{9}$ Thus, in the origins of the post-war European integration process, federal and cosmopolitan notions and values reappeared in European political and moral thought in connection to the aim of achieving a more peaceful and civilized world.

In spite of this intellectual background, the issue of whether the European Union meets the traits and conditions of a federal organization is still a matter for scholarly discussion even though the Union has gone even further than earlier modern and contemporary intellectuals ventured to imagine. For example, Kant neglected to grant any judicial and constitutional powers to the international federation of peace. In contrast, the European Union has prompted a multi-level judicial architecture for the protection of basic rights and the so-called constitutionalization of the founding treaties, creating a form of dual citizenship, the national and the supranational (Shaw 1998, 293-317; Fabbrini 2010; Fabbrini 2004, 547-569; Stone Sweet 2012, 53-90; Neegaard and Nielsen eds., 2012; Postigo 2014, 172-190).

that «the pooling of coal and steel production should immediately provide for the setting up of common foundations for economic development as a first step in the federation of Europe, and will change the destinies of those regions which have long been devoted to the manufacture of munitions of war». Robert Schuman's Declaration is accessible on the Internet: European Union's official webpage: http://europa.eu/about-eu/basic-information/symbols/europe-day/ schuman-declaration/ [accessed 20 May 2014].

9 For a comparison of Kant's 1795 essay and the United Nations' system for the protection of human rights, see Habermas 1997, 121. 
In addition to these achievements, the European Union has given rise to a supranational political sphere which is founded on the principle of representative democracy (Article 14 of the Treaty of the European Union, TEU). There are, nonetheless, important peculiarities that should not be overlooked. For instance, in the European Union, two forms of representation and decision-making coexist: the supranational and the intergovernmental. While the Council and the European Council reflect the interests of the (currently) twenty-eight member states, the European Parliament represents the will of European citizenship or Euro-demos (TEU, Art. 14, 2). The two dimensions, the intergovernmental and the supranational; states' interests; and European citizenship -which is reflected in proportional representation in the European Parliament- coexist in a somewhat uneasy way at the European level. The European Parliament is the only institution of the Union that has direct elections; the Council of the European Union and the European Council are only indirectly legitimated and elected through national elections (Wiesner 2014, 109).

The European Union is the only supranational organization with a democratically elected Parliament. Nevertheless, it is frequently criticized for its lack of transparency and «democratic deficit». ${ }^{10}$ Over the last decades, scholars, political analysts and citizens alike have complained that the European Union has become a bureaucratic organization too distant from the people and where supranational decision-making mechanisms are opaque to citizens. The causes and symptoms of the «democratic deficit» of the Union that have been underlined over the past decade range from the persistent interstate imbalances and excesses of intergovernmental politics, to the lack of transparency, absence of European public opinion and Euro-demos, and a weak European Parliament. In spite of the recent reforms introduced by the Lisbon Treaty in 2007 to strengthen the European Parliament, enhance citizens' participation in the decision-making processes and improve transparency, the management of the 2008 economic crisis has shown the limits and shortcomings of an incomplete integration and provoked much criticism due to the weak, if not actually nonexistent, role of the European Parliament in the austerity measures approved by the Troika ${ }^{11}$

10 On the debate on the democratization of the European Union see Schmitter 2000; Schmitter 2001; Schmitter and Trechsel 2007; for a different viewpoint underscoring the singularities and significance of the European Parliament, see Wiesner 2014, 101-120.

11 The expression Troika, which comes from the Russian word for a group of three, has been increasingly used since the outbreak of the Eurozone economic crisis to describe a triumvirate of international institutions (the European Commission, the European Central Bank and the International Monetary Fund) that laid down the stringent austerity measures in order to provide bailouts for indebted peripheral European states, such as Ireland, Portugal and Greece. 
to tackle the Euro-zone crisis (Schmidt 2013; Wiesner 2014, 107; Beck and Grande 2006, 321-323).

In contrast, scholars such as Richard Bellamy and Kalypso Nicolaïdis have argued in favor of a demoi-cracy. In other words, they believe that the democratization of the European Union should be based on the reinforcement of national parliaments instead of strengthening supranational institutions such as the European Parliament. On the other hand, the European integration process raises many questions regarding the concrete limits and borders of the so-called European continent and European values or identity (Bellamy 2013, 499-516; Nicolaïdis 2013; Judt 2011; Hellström 2006).

Undoubtedly, these issues require thorough reflection. However, it is important to bear in mind that the European Union is not a traditional nation-state; it is not even a federal one. ${ }^{12}$ On the contrary, it can be viewed as a unique organization; a post-national polity where national and supranational democratic processes (elections, representation, parliamentary debate and procedures, decision-making, accountability and legitimation-mechanisms) coexist and intertwine ${ }^{13}$ The controversy regarding the political nature and definition of the European Union is partly nominal and partly a matter of conceptual clarification and adaptation. If you stretch the concepts of federalism and the Union slightly, they might fit together. However, instead of trying to anachronistically apply old concepts and political categories to the European Union, it seems more reasonable to view the Union as a new and unique non-state polity. Accordingly, European supranational decision-making procedures and shortcomings should not be assessed and addressed according to the political framework of the Westphalian nation-state system nor modern representative democracy. The question that remains is whether such a non-state polity can ultimately be democratized (see Schmitter 2000; Schmitter 2001).

12 It is, however, a matter of debate whether the European Union can be viewed as a federal organization like the United States (Castaldi 2007, 1-93; Fabbrini 2004, 547-569). It should be noted that the Lisbon Treaty has attributed the European Union full legal personality, it is hence able to sign international treaties within its area of competence and join and international organization. See the Treaty of Lisbon amending the Treaty on European Union and the Treaty establishing a European Community (OJ 306, 17 December 2007), entered into force on 1 December 2009, summary, http://www.europarl.europa.eu/ftu/pdf/en/FTU_1.1.5.pdf [accessed 8 October 2014].

13 The concept of a post-national (European) citizenship and constellation has become increasingly relevant in academic debates since the 1990s. See (Shaw 1998, 293-317; Habermas 1995; Habermas 1998; Held 1995). 
However, although the debate on the European Union democratization and institutional reform is certainly pressing, I would like to raise here other related queries and considerations. How distant or different is the European Union from modern and postwar cosmopolitan ideals? Has the European Union really prevented and eradicated the evils that once triggered the two world wars? Has the European Union achieved the goals of economic growth and durable peace, cosmopolitan values and education, the free movement of citizens, the enhancement and promotion of its alleged core principles including freedom, democracy, human dignity, the rule of law and the respect for human rights?

The improvements and achievements of the European integration process in the past decades cannot be ignored. The European continent has enjoyed more than sixty decades of generally peaceful coexistence among states (with the exceptions of the wars in the former Yugoslavia and the Ukrainian conflict); several decades of economic prosperity in Western democracies that have, at least until the 1980s, managed to combine a market economy and a welfare state system; the creation of a quasi-federal multi-level judicial architecture for the protection of basic rights; the move toward Eastern Europe in 2004 and 2007 that demolished the Iron Curtain that had divided the democratic West and the communist East for more than six decades; the Erasmus exchange program mobilizing thousands of learners and staff throughout the European Union and beyond every year: ${ }^{14}$ and recent reforms of the Treaty of the European Union (the Lisbon Treaty) improving transparency, strengthening the European Parliament and creating a new channel for citizens' direct involvement in the decisionmaking processes of the Union with the European Citizens' Initiative. ${ }^{15}$

14 For the period 2014-20 the Erasmus + Program has been granted an overall sum of 16.454 billion EUR in funding. The program includes Actions addressing both learners and staff in the fields of higher education (including its international dimension), vocational education and training, school education, adult education, youth (including its international dimension) and the Jean Monnet Program addressed to researchers on the field of the European Union. All EU member states can fully take part in all the Actions of the Erasmus + Program, along with non-European Union countries such as the Republic of Macedonia, Iceland, Liechtenstein, Norway and Turkey. Moreover, several other non-European member states can take part in certain Actions, including states of the western Balkans, Eastern Partnership countries of the former URS, south Mediterranean states and the Territory of Russia as recognized by international law. Some Actions are also open to Partner Countries from all over the world. See the details on the official website of the program: http://ec.europa.eu/programmes/erasmus-plus/discover/guide/ index_en.htm [accessed 9 October 2014].

15 See European Commission, The European Citizens' Initiative, http://ec.europa.eu/dgs/ secretariat_general/citizens_initiative/index_en.htm [accessed 20 October 2014]. 
These achievements have been overshadowed by the outbreak of the 2008 economic crisis that revealed some of the shortcomings of the current architecture of the European Union. In addition, the crisis has triggered other equally harmful dynamics that are threatening to jeopardize civic coexistence among European peoples and citizens. I am referring to the rise of nationalist and populist parties and policies throughout the European Union. In what follows, I will briefly address this worrying phenomenon that threatens the civic life and integration of the European Union.

\section{EUROPEAN CITIZENSHIP AND THE CIVIC EUROPEAN PROJECT: SUCCESSES AND SHORTCOMINGS}

Nationalism and xenophobia are certainly not rare phenomena in contemporary European history. Historical evidence shows that when national economies fall into recession and suffer economic downturns populist anti-foreigner and nationalist discourse rises and gains popularity. In the past few years, particularly after the 2008 economic crisis, there has been an alarming growth of nationalist and populist parties throughout the European continent. ${ }^{16}$

The achievement of lasting peace and economic growth was the basic motivation for initiating the European integration process after World War II. Another good reason for building a united Europe is the enhancement of European citizenship and the improvement of its civic cohesion. The creation of the European Union has certainly brought new opportunities, rights and obligations to European citizens. Since the 1990s, and particularly after the Maastricht Treaty in 1993, the notion of European citizenship was launched and gained relevance among scholars and political scientists (Shaw 1998, 293-297).

European Union citizenship is conferred automatically on any person who holds the nationality of a European member state, and it complements, not replaces, national citizenship. Indeed, the European Union has given rise to a dual form of citizenship, the national and the supranational. Union citizenship therefore adds new rights and opportunities to national citizenship. Among other rights and opportunities enjoyed in the European Union examples include: the right to move and reside freely within the European Union; the right to vote

16 Regarding the Swedish example see Hellström's and Bevelander's article in this volume. Also see Hillebrand 2014 and «Europe's Populist Insurgents. Turning Right». 2014. The Economist, 4 July. http://www.economist.com/news/briefing/21592666-parties-nationalist-rightare-changing-terms-european-political-debate-does [accessed 20 October 2014]. 
for and stand as a candidate in European Parliament and municipal elections in one's place of residence; the opportunity to benefit from the European Commission's training programs, grants and scholarships; the right to be assisted by another member state or consulate outside the European Union under the same conditions as a citizen of that country if their own is not represented. ${ }^{17}$

It should be noted that the rulings of the European Court of Justice have played a key role in asserting the direct effect and superiority of European Union law over national legislation, complementing and reinforcing national systems for the protection of basic rights and consolidating the «constitutionalization» of the founding treaties of the European Union. Moreover, the European Charter on Fundamental Rights has become legally binding on the European Union with the Treaty of Lisbon in December 2009, which also contemplates the European Union's accession to the European Convention for the Protection of Human Rights and Fundamental Freedoms, complementing the so-called cosmopolitan judicial system. As a result, European citizens have come to enjoy a multi-level architecture for the protection of their basic rights and a quasi-constitutional federal judicial system (Fabbrini 2004, 547-569; Fabbrini 2010; Stone Sweet 2012, 53-90; Neegaard and Nielsen eds., 2012; Postigo 2014, 172-190).

In line with this legal framework, one basic feature of Union citizenship is the freedom of movement across the European Union. Along with the free movement of goods, capital and services, the free movement of citizens (and workers) across the European Union, to seek jobs, study or simply enjoy a better climate or lifestyle, is a basic goal and right enshrined in the founding treaties of the European Union. In 1990, this right was specifically regulated by the Schengen Implementation Convention. Indeed, the free movement of persons has been elevated by the European Court of Justice's case law to the status of a «fundamental right». It can be said, as Rainer Bauböck has put it, that «Union citizenship becomes relevant only once a person lives in another member state of the Union or in a third country» (quoted by Shaw 1998, 298). In fact, moving freely within the Union is the right that citizens associate most directly with European Union citizenship, and is often seen, according to Eurobarometer surveys, as the best achievement of the European Union ranking above the euro, economic prosperity and peace (European Commission 2013, 17). ${ }^{18}$

Therefore, European citizenship can be defined as «the result of a combined evolution of the free movement rules with the development of an individual

17 For a more detailed and longer list of rights and obligations of Union citizens see European Commission 2013.

18 Also see Koikkalainen 2011 and Gelatt 2005. 
rights conception» (Shaw 1998, 303). Nevertheless, the percentage of Europeans living or working in a member state other than their own is very low. ${ }^{19}$ Unlike the other three basic freedoms of movement (capital, services and goods), the free movement of workers and citizens frequently meets many obstacles in its national implementation. On the one hand, the Schengen Convention allows any country under its provisions to reestablish its national border checks for a short period of time in cases of «national security». For example, Portugal reestablished its frontier controls during the European Football Championship in 2004 and Finland did the same in 2005. Likewise, France reestablished its border controls after the July 2005 terrorist attacks in London (Gelatt 2005). In addition, the Free Movement Directive allows member states to take «all necessary measures» against European Union foreigners in cases of socialbenefit abuse, including expulsion. ${ }^{20}$

On the other hand, insofar as social and economic policies lie within the scope of state competence, and in spite of the fact that discrimination on the grounds of nationality is forbidden in the European Union, national social policies (such as unemployment insurance and benefits) do not always facilitate or encourage workers' mobility across the Union/Schengen areas (see European Commission 2013, 7-8). ${ }^{21}$ Likewise, member states have for a long time been reluctant to cede competence on the regulation of third country labor migration, in spite of the improvements made on common European regulation and cooperation on immigration matters over the two past decades (European Parliament and IOM 2009, 28).

For these reasons, despite high levels of unemployment (over 26 million

19 According to the OECD's Economic Surveys, European Union, March 2012, only 3 percent of working-age Union citizens live in a different country. Cross-border mobility within the European Union stands at an average annual rate of only 0.20 percent, while the international mobility rate in Australia is 1.5 percent and in the United States 2.4 percent. See European Commission 2013, 6.

20 Directive 2004/38/EC of the European Parliament and the Council, of 29 April 2004, Official Journal of the European Union, L 158, 30-4-2004, http://eur-lex.europa. eu/LexUriServ/LexUriServ.do?uri=OJ:L:2004:158:0077:0123:en:PDF [accessed 21 October 2014].

21 The Treaty provisions on free movement of workers provide that workers' right to accept employment offers and to move freely within the territory of the member states in order to take up such offers is subject to limitations justified on grounds of public policy, public security or public health, see «Freedom of Movement in the EU», Citizens Information, http://www.citizensinformation.ie/en/moving_country/moving abroad/freedom_of_movement_within_the_eu/freedom_of_movement_in_the_eu.html [accessed 8 October 2014]. (Itälics are mine). 
unemployed in the European Union in 2013), labor mobility within the Union is still very low and, in the past four years, the number of unfilled vacancies in the member states has risen. Businesses are facing difficulties in hiring qualified workers (European Commission 2013, 11).

Although labor mobility «could be a powerful adjustment mechanism to address imbalances and contribute to a better matching of jobs and skills, whilst restoring dynamism and alleviating social suffering among EU citizens», and it «increases social and cultural interactions within the European Union and creates closer bonds between Europeans, generating mutual economic benefits for businesses and citizens, including those who remain at home, as the European Union steadily removes internal obstacles» (European Commission 2013, 11, 3), the current trend on the European continent seems to be moving in the opposite direction. The outbreak of nationalist and anti-foreigner discourse is posing serious challenges to the enhancement of European Union citizenship. $^{22}$

For instance, electoral success of far right populist parties, such as the National Front in France and the UKIP (United Kingdom Independent Party) in recent national and European elections, has dragged the conservative and center right parties toward more radical speeches regarding immigrants (including workers from within the European Union) and European Union membership. For instance, following the break out of UKIP in the 2014 European Elections on 19 July 2014, Prime Minister David Cameron, of the United Kingdom, outlined a reform of the immigration law whose main aim is «to put Britain first» when it comes to access to social and job benefits and has promised a referendum on British membership of the European Union. ${ }^{23}$

Likewise, at the height of the economic crisis, a committee of experts appointed by Chancellor Angela Merkel, of Germany, has released an interim report recommending limits to residency rights for job-seekers in Germany from other European Union member states. ${ }^{24}$ On 9 February 2014 Switzer-

22 See «Europe's Populist Insurgents. Turning Right» quoted above.

23 The media coverage of this issue is large in the UK as well as outside the UK. For instance, see "Cameron Outlines Immigration Curbs 'to Put Britain First'», BBC News, 19 July 2014, http://www.bbc.com/news/uk-politics-28537663 [accessed 8 October 2014]; «David Cameron: We're Building an Immigration System that Puts Britain First», The Telegraph, 28 July 2014, [accessed 8 October 2014]; Denis McShane, «Britain's Party Political Gatherings Fret and Worry Over Europe», Social Europe Journal, 7 October 2014, http://www.social-europe.eu/2014/10/britains-partypolitical-gatherings-fret-worry-europe/ [accessed 8 October 2014].

24 «German Panel Lays Down Restrictions on EU Immigrants». 2014. EurActiv. 
land, the core of the most prosperous European economies, voted and passed an initiative by the Swiss People's Party (SVP) calling for the introduction of quotas on immigrants from the European Union. While Switzerland is not a member state of the European Union, it has signed bilateral agreements with the Union allowing free movement for immigrants. The Swiss People's Party can be described as a right-wing anti-foreigner party whose main goal is to restrict free movement and limit the bilateral accords that Switzerland made with the European Union. Although, the initiative passed by a small margin (50.3 percent yes votes), its implications are quite significant since the Constitution of Switzerland now states that «immigration shall be restricted by limits on numbers and by quotas». This in turn means that new restrictions on immigration, such as limitations on family reunification and seasonal workers will be more easily approved. ${ }^{25}$

In Sweden, the 2014 national elections have put an end to eight years of conservative rule, replacing former Prime Minister Fredrik Reinfedt with the leader of the Social Democratic Party, Stefan Loefven. The striking thing is that the election outcome, with a voter turnout of over 85 percent, has given 43.6 percent of the votes to the Social Democratic-led left-green party and 39.4 percent of the votes to the center-right alliance. Obviously, neither group has been able to achieve an absolute majority, which is due to the unprecedented performance of the populist anti-immigration party, Sweden Democrats, who gained 13 percent of the votes. Prime Minister Stefan Loefven has explained such a rise of the populist Swedish Democrats in the following terms: it could be due to the «increasing inequalities, decreasing school results, worsening equality of social services and increasing unemployment», in his words, «the increasing support of the Swedish Democrats is not a result of growing racism or even wide spread xenophobia, but rather a result of wider and wider gaps in society». ${ }^{26}$

com, 37 March. http://www.euractiv.com/sections/social-europe-jobs/german-panellays-down-restrictions-eu-immigrants-301168; «Poverty Migration: Berlin Backs UK’s ‘Benefit Tourism' Offensive». 2013. Spiegel Online International. 29 November. http://www.spiegel.de/international/europe/germany-joins-uk-in-calling-for-measuresagainst-benefit-tourism-a-936350.html [accessed 21 October 2014].

25 Rechsteiner, Andreas Rieger and Renzo Ambrosetti. 2014. "The Outcome of the People's Initiative in Switzerland -A Huge Setback!» Social Europe Journal 20/02/2014. http:// www.social-europe.eu/2014/02/peoples-initiative/ [accessed 21 February 2014].

26 Matt Browne, «An Interview with Stefan Löfven». 2014. Social Europe Journal, 23 September, http://www.social-europe.eu/2014/09/stefan-lofven/ [accessed 9 October 2014]. For a different analysis and explanation relying on media exposure see Hellström's and Bevelander's article in this volume. 
These are just a few examples to illustrate the rise of anti-European as well as populist anti-foreigner discourse and policies across Europe, even in the core prosperous European Union member states. Unfortunately, more examples could be provided, including widespread hostilities towards nonEuropean immigrants, particularly Muslims, after terrorist attacks in New York, Madrid and London (see Jakobsen in this volume) and ethnic-nationalist separatist movements in Catalonia, Spain. Far-right and/or far-left populist and nationalist parties are currently present in many European democracies, such as France, Greece, Spain, Austria, Belgium, the Netherlands, Sweden, Denmark, Finland, Norway, the United Kingdom, Switzerland, the Balkan states, and Eastern Europe. In spite of their local specificities and idiosyncrasies, all of them have in common their chauvinist "us vs. them" stand. They confuse the nation (and ethnicity) with citizenship and are unable to acknowledge the universal sense of modern and contemporary citizenship. This misunderstanding is particularly relevant in the context of the European Union to the extent that it undermines the basic cosmopolitan dimension of the European integration project and threatens civic coexistence among Union citizens. Integration issues are certainly not simple or easy to handle; a great deal of wise intellectual effort is required to adjust liberal constitutional principles to the increasing pluralism, immigration flows and religious diversity in most European states (Jakobsen 2014, 19-35; Alnes 2014, 70-90). ${ }^{27}$ However, in order to be competitive and enhance the civic dimension of the integration process, European Union states should foster citizens' intra-European mobility and equal opportunity (on the civic focus on immigration debates see Rosales 2014).

To summarize, some questions can be raised: What are the causes of the proliferation of anti-European and nationalist discourse across the European Union? Has the 2008 euro-zone economic crisis played any role in the outbreak of nationalism, populism and anti-immigration parties? Are the causes rooted in the spread of international jihad? Above, we have seen one explanation: Sweden's Prime Minister Stefan Loefven underlined the fact that the increasing support of the Swedish Democrats «is not a result of growing racism or even wide spread xenophobia, but rather a result of wider and wider gaps in society». ${ }^{28}$ In my view, along with monetary harmonization and the creation of a free market, European integration should enhance European citizenship and its civic cohesion and education. The management of the economic crisis

27 Also see Jan Harald Alnes', Jonas Jakobsen's and Melina Duarte's articles in this volume.

28 Also see «Europe's Populist Insurgents. Turning Right». 
has not helped much in lowering the gaps between member states and citizens. The focus should be, in my view, on citizenship, including social, political and civil rights which are key dimensions of contemporary citizenship, as well as education in cosmopolitan values (Marshall 1950; Shaw 1998, 301). Discrimination on the grounds of nationality is forbidden in the European Union. Both supranational leaders and courts should improve their efforts to prevent national governments from launching and implementing xenophobic discourses and restrictions on the free movement of European Union citizens across member states when they are contrary to European law.

Along with equal opportunity, the democratization of the Union is an urgent task in the enhancement of European citizenship. As Frank Schimmelfennig has put it, the management of the economic crisis is once again based on a functionalist process of «endogenous preference change and functional spill over» $(2014,1)$. This functionalist account may bring new opportunities for pushing European integration further, as it is the case of the recently approved European banking union (financial integration) ${ }^{29}$ However, citizens are more than mere passive observers of intergovernmental negotiations, they are the cornerstone of European integration and should claim their civic and democratic rights in the European Union.

The European Union currently faces enormous challenges to ensure its prosperous future. In the globalized world, European states cannot compete and move forward in conflict with one another; they might be forced to cooperate and integrate if Europe is to play a significant role in the world. Not so many decades ago, xenophobia, racism and intolerance led the European continent to barbarism. As we have seen above, civic cosmopolitanism was, after World War II, the best antidote against the unfortunate split of Europe, and it might also be the case in the current European Union.

\section{REFERENCES}

ALNES, J. H. 2014: «Democratic Education and Reasonable Pluralism». In Jan Harald Alnes and Manuel Toscano, eds., Varieties of Liberalism: Contemporary Challenges. Newcastle upon Tyne: Cambridge Scholars Publishing, 70-90.

29 European Commission, banking union, http://ec.europa.eu/internal_market/finances/ banking-union/index_en.htm [accessed 20 October 2014]. 
AREND, H. 1976: The Origins of Totalitarianism. Orlando: A Harvest BookHarcourt, Inc.

AYZAGAR, J. and G. CAPELLÁN DE MIGUEL. 2003: «Federalismo», Diccionario político y social del siglo XIX español, Javier Fernández Sebastián and Juan Francisco Fuentes, dirs., Madrid: Alianza Editorial, 305-10.

BURGESS, M. 2000: Federalism and the European Union: The Building of Europe 1950-2000. London: Routledge.

BECK, U. and E. GRANDE. 2006: La Europa cosmopolita. Sociedad y política en la segunda modernidad. Barcelona: Paidós.

BELLAMY, R. 2013: «'An Ever Closer Union Among the Peoples of Europe’: Republican Intergovernmentalism and Demoicratic Representation within the EU». Journal of European Integration, 35 (5), 499-516.

CASTALDI, R. 2007: «A Federalist Framework Theory on European Integration». Centro Studi Federalismo 1-93.

DOSENRODE, S. 2010: «Federalism Theory and Neo-functionalism: Elements for an Analytical Framework». Perspectives on Federalism, 2 (3), 1-28.

EUROPEAN COMMISSION. 2013: EU Citizenship Report 2013. Brussels, http://ec.europa.eu/justice/citizen/files/2013eucitizenshipreport_en.pdf [accessed 17 October 2014].

EUROPEAN PARLIAMENT and INTERNATIONAL ORGANIZATION FOR MIGRATION. 2009: «Laws for Legal Immigration in the 27 EU Member States». International Migration Law, Num. 16, http://publications.iom. int/bookstore/free/IML_16.pdf [accessed 17 October 2014].

FABBRINI, M. 2004: «Transatlantic Constitutionalism: Comparing the United States and the European Union». European Journal of Political Research 43, 547-569.

FABBRINI, M. 2010: «The European Multilevel System for the Protection of Fundamental Rights: A 'Neo-Federalist Perspective'». Jean Monnet Working Paper 15/10.

GARRIDO, M. 2005: «Introducción», in Immanuel Kant. Ensayos sobre la paz, el progreso y el ideal cosmopolita. Madrid: Tecnos, 9-21.

GELATT, J. 2005: «Schengen and the Free Movement of People Across Europe». Migration Policy Institute October 1, http://www.migrationpolicy. org/article/schengen-and-free-movement-people-across-europe [accessed 3 October 2014].

HABERMAS, J. 1997: «Kant's Idea of Perpetual Peace, with the Benefit of Two Hundred Years' Hindsight». In James Bohman and Matthias LutzBachmann, eds. Perpetual Peace. Essays on Kant's Cosmopolitan Ideal. Cambridge: The MIT Press, 113-155. 
HABERMAS, J. 1998: Die postnationale Konstellation. Politische Essays. Suhrkamp.

HELD, D. 1995: Democracy and the Global Order: From the Modern State to Cosmopolitan Governance. Cambridge: Polity Press.

HELLSTRÖM, A. 2006: Bringing Europe Back to Earth. Lund: Lund University.

HILLEBRAND, E. ed. 2014: Right Wing Populism in Europe -How Do We Respond? Friedrich Ebert Stiftung, International Political Analysis, May, http://library.fes.de/pdf-files/id/ipa/10756.pdf [accessed 21 October 2014];

JAKOBSEN, J. 2014: «Religion and (Mis)recognition: Alex Honneth and the Danish Cartoon Controversy». In Jan Harald Alnes and Manuel Toscano, eds., Varieties of Liberalism: Contemporary Challenges. Newcastle upon Tyne: Cambridge Scholars Publishing, 19-35.

JUDT, T. 2011: A Grand Illusion? An Essay on Europe. New York and London: New York University Press.

KANT, I. 2005: «Sobre la paz perpetua» in Ensayos sobre la paz, el progreso y el ideal cosmopolita. Madrid: Cátedra, 141-189.

KOIKKALAINEN, S. 2011: «Free Movement in Europe: Past and Present». Migration Policy Institute, April 21. http://www.migrationpolicy.org/article/ free-movement-europe-past-and-present [accessed 3 October 2014].

LUTZ-BACHMANN, M. 1997: «Kant's Idea of Peace and the Philosophical Conception of a World Republic». Perpetual Peace. Essays on Kant's Cosmopolitan Ideal, James Bohman and Matthias Lutz-Bachmann, eds. Cambridge, MA: The MIT Press, 59-79.

MARSHALL, T. H. 1950: Citizenship and Social Class. Cambridge: Cambridge University Press.

MENON, A., and S. WEATHERILL. 2007: «Democratic Politics in a Globalizing World: Supranationalism and Legitimacy in the European Union». Law, Society and Economy Working Papers 13, 1-29.

MONNET, J. 1985: Memorias. Madrid: Siglo XXI.

MULLER, J. Z. 2008: «Us and Them. The Enduring Power of Ethnic Nationalism».Foreign Affairs March/April, 1-11. www.foreignaffairs.org [accessed 4 April 2008].

NEEGAAR, U., and R. NIELSEN, eds. 2012: European Legal Method in a Multi-Level EU Legal Order. Denmark: DJOF Publishing.

NICOLAÏDIS, K. 2013: «Pragmatism, Idealism and European Demoicracy». Social Europe Journal, 15 July 2013 http://www.social-europe. $\mathrm{eu} / 2013 / 07 /$ pragmatism-idealism-and-europeandemocracy/?utm 
source $=$ feedburner\&utm_medium $=$ feed\&ut $m \_$campaign $=$Feed $\% 3 \mathrm{~A}+\mathrm{s}$ ocialeurope $\% 2$ FwmyH $+\% 28$ Social+Europe + Journal $\% 29$ [accessed 2 August 2013].

NUSSBAUM, M. 1997: «Kant and Stoic Cosmopolitanism», James Bohman and Matthias Lutz-Bachmann, eds., Perpetual Peace. Essays on Kant's Cosmopolitan Ideal. Cambridge, MA: The MIT Press, 25-59.

POSTIGO, M. 2014: «Beyond the Nation-State: The European Union and Supranational Democracy». In Jan Harald Alnes and Manuel Toscano, eds., Varieties of Liberalism: Contemporary Challenges. Newcastle upon Tyne: Cambridge Scholars Publishing, 172-190.

RIVERA GARCÍA, Antonio. 2000: «La idea federal en Pi y Margall», Araucaria 4, 113-141.

RIVERA GARCÍA, A. 2003: «Federalismo y derecho cosmopolita en el marco de la crisis global de la soberanía». Daimon. Revista de Filosofía 29, 155170.

ROSALES, J. M. 2014: La integración cívica de los inmigrantes. Un ensayo sobre inmigración, ciudadanía y derechos. Barcelona: Horsori Editorial.

SCHMIDT, V. 2013: «Democratizing the Eurozone». Social Europe Journal 5 May. http://www.social-europe.eu/2012/05/democratizing-the eurozone/?utm_source=feedburner\&utm_medium=feed\&utm_campaig $\mathrm{n}=$ Feed $\% 3 \mathrm{~A}+$ social-! europe $\% 2 \mathrm{FwmyH}+\% 28$ Social+Europe + Journal $\%$ 29 [accessed 21 May 2012].

SCHIMMELFENNIG, F. 2014: «European Integration in the Euro Crisis: The Limits of Postfunctionalism». Journal of European Integration February 2014, 1-17.

SCHMITTER, PH. 2000: How to Democratize the European Union - and Why Bother? Lanham: Rowman \& Littlefield Publishers.

SCHMITTER, PH. 2001: «What Is There to Legitimize in the European Union ... and How Might this Be Accomplished?» Jean Monnet Working Paper 6/01, http://www.eui.eu/Documents/DepartmentsCentres/SPS/Profiles/ Schmitter/LegitimizeEU.pdf [accessed 8 November 2012].

SCHMITTER, PH. and A. H. TRECHSEL, coords. 2007: The Future of Democracy in Europe: Trends, Analysis and Reforms. A Green Paper for the Council of Europe. Strasbourg: Council of Europe. http://www.thefutureofrepresentativedemocracy.org/files/pdf/resources/schmitter_thefutureofDemocracyinEurope.pdf [accessed 9 November 2012].

SHAW, J. 1998: "The Interpretation of European Union Citizenship». The Modern Law Review, 61, 3, 293-317. 
STONE SWEET, A. 2012: "A Cosmopolitan Legal Order: Constitutional Pluralism and Rights Adjudication in Europe». Global Constitutionalism $1,1,53-90$.

WEILER, J. H. H. 2012: «In the Face of Crisis: Input Legitimacy, Output Legitimacy and the Political Messianism of European Integration». Journal of European Integration 37, 7 (November), 825-841.

WIESNER, C. 2014: «The European Parliament as Special Parliament and Political Actor: Dissensus, Debate and Deliberation as Tools». In Kari Palonen, José María Rosales and Tapani Turkka, eds., The Politics of Dissensus. Parliament in Debate. Santander and Madrid: Cantabria University Press and McGraw-Hill, 101-127.

ZWEIG, S. 1976: Die Welt von Gestern. Zürich: Williams Verlag. 